Paideusis

\title{
Philosophy of Education: Overcoming the Theory-Practice Divide
}

\section{Megan Laverty}

Volume 15, Number 1, 2006

URI: https://id.erudit.org/iderudit/1072692ar

DOI: https://doi.org/10.7202/1072692ar

See table of contents

Publisher(s)

Canadian Philosophy of Education Society

\section{ISSN}

0838-4517 (print)

1916-0348 (digital)

Explore this journal

Cite this article

Laverty, M. (2006). Philosophy of Education: Overcoming the Theory-Practice Divide. Paideusis, 15(1), 31-44. https://doi.org/10.7202/1072692ar

\section{Article abstract}

I argue that philosophy has a dual role in teacher education: first, it prompts teachers to take individual responsibility for and become more reflective about the values expressed by their teaching practices so as to enable them to teach with greater authenticity; second, it provides teachers with a disciplinary technique that is useful in the facilitation of student reflection and dialogue so as to enable students to think and live more authentically. In this paper, I focus on the former and suggest that because teaching practices are expressions of values, teachers need to become more aware of competing conception of the human good(s) -including their own-and how these inform their relationship to disciplinary expertise, educational institutions, and teaching. I argue that authentic teaching necessitates: a conviction that individuals are improved, as human beings, by what it is they study; a deepening engagement with what this conviction means; and a commitment to its truth by way of how one engages with one's discipline and students. It is in this regard that I explore Plato's dialogue Gorgias, in particular, the example of Socrates, his conversations with Callicles, as well as his distinction between sophistry/pandering and educating/healing. In the final part of the paper, I argue that, assuming I am correct about the necessity and value of teaching authentically, philosophy_conceived of as honest, rigorous, ongoing, open-ended and dialogical engagement with our convictions-should be an integral part of any good teacher education program.
This document is protected by copyright law. Use of the services of Erudit (including reproduction) is subject to its terms and conditions, which can be viewed online.

https://apropos.erudit.org/en/users/policy-on-use/ 


\title{
Philosophy of Education: Overcoming the Theory-Practice Divide ${ }^{1}$
}

\author{
MEGAN LAVERTY \\ Teachers College, Columbia University
}

I argue that philosophy has a dual role in teacher education: first, it prompts teachers to take individual responsibility for and become more reflective about the values expressed by their teaching practices so as to enable them to teach with greater authenticity; second, it provides teachers with a disciplinary technique that is useful in the facilitation of student reflection and dialogue so as to enable students to think and live more authentically. In this paper, I focus on the former and suggest that because teaching practices are expressions of values, teachers need to become more aware of competing conception of the buman good(s) including their own - and how these inform their relationship to disciplinary expertise, educational institutions, and teaching. I argue that authentic teaching necessitates: a conviction that individuals are improved, as human beings, by what it is they study; a deepening engagement with what this conviction means; and a commitment to its truth by way of how one engages with one's discipline and students. It is in this regard that I explore Plato's dialogue Gorgias, in particular, the example of Socrates, his conversations with Callicles, as well as his distinction between sophistry/pandering and educating/healing. In the final part of the paper, I argue that, assuming I am correct about the necessity and value of teaching authentically, philosophy — conceived of as honest, rigorous, ongoing, open-ended and dialogical engagement with our convictions — should be an integral part of any good teacher education program.

At a time when the philosophy of education is under threat worldwide, it is imperative that philosophers re-articulate the role of philosophy in education and more specifically the role of philosophy of education in the preparation of teachers. This article attempts such a re-articulation. Drawing upon Plato's Gorgias, I argue that the role of philosophy-construed substantively as well as methodologically-in teacher education is akin to its role in life, specifically in learning to live well. ${ }^{2}$

\footnotetext{
${ }^{1}$ I am indebted to Raimond Gaita's comments on teaching and his moral philosophy more generally for inspiring this article: Good and Evil: An Absolute Conception (London: Macmillan Press Ltd., 1991) and A Common Humanity: Thinking about Love, Truth and Justice (Melbourne: Text Publishing, 1999). I would like to thank Laurance Splitter who read and commented on an earlier version of this article as well as the reviewer from Paideusis.

2 An article that considers the educational significance of Plato's Gorgias is by Thomas L Pangle, entitled, "Plato's Gorgias as a vindication of Socratic education" in Polis, 1991, 10 (1-2), pp. 3-21.

(C) Copyright 2006. The author, Megan Laverty, assigns to Paideusis the right of first publication and educational and non-profit institutions a non-exclusive license to use this document for personal use and in courses of instruction provided that the article is used in full and this copyright statement is reproduced. Any other usage is probibited without the express permission of the author.
} 


\section{Philosophy of Education: Current Conceptions and Practice}

Philosophy of education informs and is informed by, philosophies of mind, philosophies of the respective disciplines, epistemic, linguistic, moral, and political theories as well as phenomenology. To discuss a philosophy of education is to examine and evaluate these other philosophies and theories as they apply to educational issues. Formal education occurs within, and to an extent is framed by, informal education; in particular, popular culture is increasingly being recognized as a powerful educative force in today's society. ${ }^{3}$ Seen in this way, philosophy of education dovetails with cultural studies, the philosophical foundation of which is more far ranging than that which is normally associated with education, and includes the writings of such philosophers as Karl Marx, Theodor Adorno, Jacques Derrida, Michel Foucault and others. Following Martha Nussbaum, and to a certain extent, Maxine Greene, I assume that one of the goals, if not the exclusive goal, of education, is to enable individuals (but in this case teachers in particular) to take responsibility for their own thinking and that philosophy is a necessary - albeit not sufficient - condition for the achievement of this goal. ${ }^{4}$ In other words, given the centrality of education in human life, and also the centrality of philosophy to the normative ideal of becoming educated, it is imperative that individuals - especially teachers and teacher educators - reflect philosophically on education.

If philosophy of education, understood in this broadly inclusive way, has a role in teacher preparation then it also requires a correspondingly broad pedagogy or teaching approach. It needs to be communicated to students that the aim of studying philosophy of education is not simply to know its theories, the authors of those theories, and the chronological order in which they occur; nor to acquire information or even a trained ability to recapitulate theories. The primary aim is to engage, in an open, honest, and lively way, with the theoretical frameworks. Arguably such engagement necessitates that students have knowledge and mastery of these theories but the context and emphasis are different. Students immerse themselves in theory not for the sake of the theories themselves but for the understanding they provide both about education and their own individual preconceptions and suppositions. Theories are appropriated for application and criticized in light of that application; the students gain greater awareness of what they believe, as well as refine what they believe through a process of critical reflection. The teacher educator is represented as having a certain expertise in philosophy, but he or she invites the students to utilize this expertise in their reflections and the development of their own philosophical insights. Accordingly, the philosophy of education classroom becomes an open, dynamic, inquiring, self-correcting, and dialectical environment. ${ }^{5}$

\section{Philosophy and Life}

Drawing from Plato's Gorgias, I suggest that we think of teaching in the same way as life: namely as something that can be practiced and spoken about either authentically or in-authentically. And just as

\footnotetext{
${ }^{3}$ For a brief summary of how popular culture does this and its significance for Giroux's cultural pedagogy refer to Weiner, Eric, "Making the Pedagogical: (Re) Turn: Henry Giroux's Insurgent Cultural Pedagogy in JAC, Volume 21, Number 2, Spring 2001 pp. 434-451.

${ }^{4}$ Nussbaum, C. Martha, Cultivating Humanity: A Classical Defense of Reform in Liberal Education (Cambridge, Massachusetts: Harvard University Press, 1997), in particular, Chapter One, "Socratic Self-Examination", pp. 1549. Green Maxine, Landscapes of Learning (New York: Teachers College Press, 1978), in particular, Section One, "Emancipatory Education" and Section Two, "Social Issues", pp. 1-158. I make a qualified reference to Maxine Greene because although she has edited a book of philosophical readings for teachers, it is unclear how she sees precisely the role of philosophy in this process of self-actualization or wide-awakeness.

${ }^{5}$ For one of the many discussions on how to do this, refer to "Teaching Philosophy as a Life Skill" Teaching Pbilosophy, 21:2, June 1998, pp. 119-130.
} 
serious and responsible philosophical reflection leads to, and is constitutive of, living more authentically, I suggest the same is true for teaching. Serious and responsible philosophical reflection enhanced by theoretical understanding - enables educators to engage with their respective disciplines, and others who are similarly engaged, with greater authenticity.

The reasons for favoring a philosophical education in relation to teaching are the same as those for favoring philosophy in relation to life. Others cannot live our lives for us, just as other teachers cannot teach for us. The particular specificities - cultural, historical, material, corporeal, interpersonal, psychological - associated with life, as with teaching, make it impossible to live life by a set of fixed rules, just as it is impossible to teach by adherence to a set of methods or rules. Even if it were possible to devise a set of rules encompassing all people, at all times in all situations, we would still need to apply these rules: to interpret them and the situations in which we see them as being applied. In either of these situations, we exercise judgement, and in so doing, implicate ourselves in a range of conceptual and normative commitments. In the attempt to find the right way to live our own life, we look to other lives that speak to us about the possibilities for living: lives that stand out for us as particularly laudable and worthwhile. The manner in which a father gently listens to his daughter, or a son maintains the graves of his deceased parents, can speak to us about the possibilities for, and potential meaningfulness of, familial love; the consideration an individual has for her pet cat can speak to us about the possibilities for, and potential meaningfulness of, human-animal relations. ${ }^{6}$ To appreciate how someone lives their life, though, is not necessarily to transpose what that individual does to the context of one's own life: I don't necessarily have to buy a cat or take up maintenance of my parents' graves. Such actions may just not 'ring true' in the context of my own life (I might be allergic to cats and not particularly like them and I may not have had very good relations with my parents). Rather, in what I do, I would want to capture, in a way that makes sense of my own life, the quality of what I appreciate.

Similarly with teaching, I might in the process of becoming a teacher, look to teachers I have admired and respected. I might think about their teaching in relation to what they do. But to simply do what they do is not to become the good teacher that they are. I must teach in a way that is meaningful for me and the particularities of my situation - geographical, historical, psychological, cultural, and political. To do this in teaching, as in life, requires three things. First, we need to be able to identify what we believe and what we mean by our concepts, in order to determine whether or not they accord with the conceptual and normative commitments of our actions. Second, we need to be able to evaluate what we are compelled by, as well as our beliefs and commitments to ensure that both are as truthful as possible. Third, we need to determine the practical implications of our beliefs and commitments, both as a means of evaluating them and as a means of developing practices properly reflective of them. In all three cases, philosophy of education has a unique role to play in relation to teaching. It alerts us to the essentially contested nature of key concepts - what it is to be "educated," a "child," a "learner," an "educator," and so on. It provides us with a reliable method by which to evaluate and refine these concepts. Finally, it enables us to see the intimate connection between our conceptual and normative commitments and the practices they inform. ${ }^{7}$

An illustration of this is found in Paulo Freire's work and the distinction he makes there between transmission or "banking" education, and dialogical or problem-solving education, identifying the former as oppressive and the later as liberating. ${ }^{8}$ One doesn't have to agree with Freire's diagnosis of

\footnotetext{
${ }^{6}$ For a discussion of these and related issues along these lines refer to Diamond, Cora, The Realistic Spirit: Wittgenstein, Philosophy and the Mind (Cambridge, Massachusetts: Massachusetts Institute of Technology, 1991), Chapters Eleven to Fifteen, pp. 291-382.

${ }^{7}$ Gallie, W.B., Philosophy and the Historical Understanding (London: Chatto and Windus, 1964), Chapter Eight, "Essentially Contested Concepts" pp. 157-191.

${ }^{8}$ Refer particularly to Pedagogy of the Oppressed, (New York: The Seabury Press, 1972), Pedagogy of Freedom: Ethics, Democracy and Civic Courage (Lantham, Boulder, New York and Oxford: Rowman and Littlefield Publishers Inc., 1998).
} 
traditional education in order to appreciate that the physical arrangement of a class room - how the seating is arranged, where the teacher places herself in the classroom, whether she sits or stands relevant to whether the students sit or stand and so on - is neither innocent, practical, nor a function of environment. Nor does one have to accede to Freire's ideological or political analysis in order to appreciate that arrangements are informed by conceptions of what it is to learn, what the role of the teacher is in relation to the student, what the character of the student-student and student-teacher relationships should be, what role class time has to non-class time, and so on. Insofar as pedagogy is performative, it is therefore normative and so implies innumerable judgements about what should be the case - these in turn being open to criticism, revision, and future realization. Incorporating philosophy of education into the preparation of teachers serves simultaneously to remove philosophy from the reified atmosphere of abstraction and theory - bringing it closer to practice - and to rescue practice from its utilitarian and instrumental paradigms. ${ }^{9}$

Philosophy of education has other important implications for the quality of teaching. For example, when taught well, it provides teachers with a philosophical competency that, if applied to their classrooms, will enrich conversations, enabling students to build upon one another's ideas; it will also evaluate ideas with respect to consistency, coherence, and relevance, and detect when prejudice and ideology disguise themselves as reason. Such a base is important given the emphasis in today's classrooms on cooperative learning and dialogical problem solving, and the striking absence of effective ways for establishing genuinely collaborative thinking. The philosophical competency teachers derive from studies in philosophy also extend beyond the classroom, empowering teachers to engage with and reflect upon new educational approaches. Rapid theoretical and material changes, compounded by the lack of time that teachers have to absorb them, can result in teachers feeling either beholden to or fearful of new educational theories and approaches. If teachers already have a strong sense of the complexity of education, complemented by some level of philosophical competence, then they will be able to identify and interact with the underlying assumptions of these new approaches, and with the relationships of these assumptions to the other assumptions already operative within the educational framework. In turn, this will enable them to endure both the changing fashions within education and the pretensions inherent in its shifting ideologies.

Perhaps more importantly, it is becoming apparent that children in the developed countries, at least, are spending more time than ever before in educational institutions. Many children attend childcare from the time they are babies, often for ten to twelve-hour days; many also attend before and after school care, and adolescents are increasingly pressured to stay at school and qualify for tertiary studies. These days an average individual is likely to spend more time at school than anywhere else, at least for the first twenty-two years of his or her life. Given that one of the aims of education is to encourage greater self-awareness and reflection, and that reflection typically takes place in relation to the complexities, joys and trials of our daily lives, then there is a pedagogical need - not to mention an humanitarian one - for students to reflect on their extensive experience of institutional education, i.e., schooling. If, as Dewey and others have argued, meaningful experience is essential for learning, then it follows that broad educational settings in which students so often find themselves should be made as meaningful as the subjects that they are learning. One way to do this is to allow students to ask, reflect upon, and critically explore together such questions as: "Why is education important?", "What is the purpose of education?" "Who are the stakeholders?" And so on. Teachers will find facilitating such explorations difficult unless they have had practice in exploring these questions for themselves. Philosophy of education has a unique role to play here, firstly because it provides teachers with

\footnotetext{
${ }^{9}$ Eric Weiner puts the point nicely - although in the context of Henry Giroux's work - when he writes, "It also liberates theories and practices of teaching and learning from the burdensome legacy of 'practicality', a code word that implies the sublimation of theory to the instrumentalization of teaching through the privileging of methodologies, techniques, practices.” JAC, Vol 21, no 2, Spring 2001, p. 436.
} 
theoretical frameworks within which to discuss these issues, and secondly because it enables teachers to facilitate constructive and disciplined discussions relating to them.

Moreover, the classroom is a crucible for the changing social, political, material and technological conditions of our world. Young students, under the guidance of their teachers, are having radically new experiences, the significance and nature of which have yet to be properly theorized. So, for example, many pre-school and elementary students have computers while students in middle and high school often have their own computers. Consequently, they are becoming increasingly reliant on information technology, communicating with individuals of all ages and of all nationalities via the internet, while at the same time the curriculum is becoming more culturally diverse. We have yet to determine the consequences of these specific changes, but we do know from the history and philosophy of education that material change of any sort challenges and ultimately transforms conceptions of the self, individuality, community, a fulfilled human life, privacy, intellectual property, and so on - which are pivotal to our thinking about education. As teachers and students are required to negotiate these changes in their day-to-day lives, they cannot rely on the academics but must begin to engage with these changes in an effort to comprehend their conceptual implications. An education in the philosophy of education gives teachers a sense of how this might be done, by considering the same processes in relation to their own growth and understanding.

\section{Teaching as Living}

My detailed argument for the analogous relationship between teaching and life and the role this gives to philosophy essentially derives from two related premises. The first is that teaching is first and foremost a practice: to be a teacher is to teach. The second is that to teach is to be in relationship. Concerning the first premise, teaching implies intentionality (deliberation, choices, decisions and actions) and so its practice implies or is informed by a set of beliefs and commitments. But these beliefs and commitments are open to being changed and revised, because another dimension of the practice of teaching is that it is undertaken and is therefore potentially transformative: teaching is as much a way of being as it is a way of doing. By this I mean that teaching doesn't simply implement a set of procedures but also enlists and reveals the individual, both in his or her particularity and entirety. This makes the individual - in differentiation from the procedures which he or she employs - vulnerable to change (something I raise in the next premise). Teaching, then, is inextricably and inevitably connected with who one is, so that to think about one's teaching is to think about one's self.

My second premise is that teaching, as with life, implies relationship - more specifically, an intricate interplay between intra- and intersubjectivities. The active dimension of teaching entails that teachers affect their students as well as themselves, and the experiential dimension of teaching entails that students affect teachers as well as themselves. To teach is to intervene in one's own and another's becoming. This is significant because I take it as given that, in spite of our best efforts, we are yet to develop a science for how to do this either effectively or appropriately, and although teacher education draws increasingly on the empirical sciences for directives and indicators, it is not itself an empirical science. Teaching in this sense is, once again, very close to life because, although we draw heavily on the empirical sciences for the living of our lives, we have yet to determine what constitutes a good human life and a method or means by which to achieve or arrive at it. Philosophers of education have had much to say about this dimension of teaching in recent years, particularly with respect to its moral and political dimensions. Paulo Freire, for example, takes as his ontological premise that human beings are self-aware, unfinished beings continuously intervening in each other's formation, of which education is a significant part. In this regard, he writes that: "In contrast to other animals who are unfinished, but not historical, people know themselves to be unfinished; they are aware of their 
incompletion. In this incompletion and this awareness lie the very roots of education as an exclusively human manifestation." 10 Similarly Nel Noddings starts from the premise that human beings exist in relation and so exist simultaneously as the one caring and the one who is cared for, of which the teaching relationship is a special case. ${ }^{11}$

I do not wish to suggest that these two premises are in some way necessary, or the only points from which to begin, although I do think they are to a certain extent inevitable. Rather, my aim in beginning with these two premises is to show the extent to which teaching resembles life - both involve being and doing as well as the constant interchange of inter- and intrasubjective relations - and the role for philosophy in both. Socrates, as he is represented in the Gorgias, is criticizing the Sophists as the professional teachers of his day. ${ }^{12}$ He criticizes them on a number of counts: they claim to be knowledgeable when often they are not; they cannot give an account of what they teach, namely oratory or rhetoric; that what they teach is but simply a knack. One of Socrates' most significant criticisms of the Sophists - which was perhaps better realized in how he lived his life, rather than by anything he said - is the disassociation between what they did as teachers of oratory and who they were as individuals, so that any transformative effects associated with being a student of oratory (which a teacher of oratory effectively is) comes to be perceived as extrinsic and contingent rather than as intrinsic and necessary. For the Sophists, the importance of oratory lies precisely in its instrumental value (it enables individuals to achieve their predetermined goals) and in a lack of teleological relevance (it assumes that the individual's goals are either already constituted or constituted by other means). Hence the Sophists' responsibilities were restricted to the quality of their students' oratorical skills and did not extend to students' reasons for wanting to become orators or the future use they made of oratory. ${ }^{13}$

While oratory is still important - indeed, it is arguably more important than ever - contemporary analogues are more likely to be technological and economic competency. It is thought to be advantageous, if not necessary, for students to be able to use technology and have an understanding of finance and business, often for no other reason than that it will enable them to achieve what they want to achieve in their lives, both professionally and personally. Hence these subjects are increasingly taught, and taught as skills-based subjects. Teachers may be held responsible for the quality of their students' skills, but this does not extend to the students' reasons for wanting to acquire these skills or the particular use they make of them. The idea that I am attributing to Plato and want to develop in this article is that the reason these subjects are taught in this way is not because they are inherently "vocational," but because of a distorted conception we have of these subjects and their respective role in human life, i.e., that their value is exclusively instrumental and not teleological. Were we to conceive of them as potentially transformative of the individuals studying them, then our teaching of them

${ }^{10}$ Friere, Paulo, Pedagogy of the Oppressed as cited in Cahn, Steven M., Classic and Contemporary Readings in the Philosophy of Education (New York: McGraw-Hill Companies, Inc., 1997), p. 469.

${ }_{11}$ Noddings, Nel, The Challenge of Care in Schools: An alternative approach to education (New York: Teachers College Press, 1992).

${ }^{12}$ I recognize that there is a great deal of work being done on the relationship between Socrates of Plato's dialogues and the historical figure of Socrates, as well as the variations in this regard between the earlier and the later dialogues. While I think this is an interesting and important question, I leave it aside for the purposes of this article and talk exclusively about Socrates as he appears in Plato's dialogues. For discussions of the issue, refer to Vlastos, Gregory, Socrates: Ironist and Moral philosopher (Ithaca, NY: Cornell University Press, 1991); Kahn, H. Charles, Plato and the Socratic Dialogue: the Philosophical Use of a Literary Form (Cambridge: Cambridge University Press, 1996); Benson, Hugh H., Essays on the Philosophy of Socrates (Oxford: Oxford University Press, 1992).

${ }^{13}$ For a representation of a defense of this idea, refer to Gorgias' speech in the Gorgias (London: Penguin Books, 1960), 456-457, pp. 34-35. Socrates frequently argues as though the instrumental character of oratory is essential to, or a function of, oratory itself, as opposed to being a function of how orators conceived and practiced it. But given his own use of oratory, his emphasis on speech over writing, the fact that his arguments are represented in the context of a broader dialogue written by Plato, there is enough evidence to suggest that Plato, and possibly Socrates, believed it was more a function of how oratory was conceived and practiced. 
would become significantly more philosophical. We see encouraging signs of this teleological shift beginning as ethics courses in business and technology are increasingly developed and required for students.

Returning to the Gorgias, Socrates' argument against the Sophists is that if you don't conceive of what you are teaching as having a transformative effect, particularly with respect to your students' values and experience of the world, then what you are doing doesn't qualify as teaching but is a form of pandering [roגaxcia]. It is a form of pandering because it supplies indiscriminate pleasure without really benefiting the individual, where benefit is understood in terms other than pleasure. It produces in the individual "gratification and pleasure" by fulfilling or "pandering" to the individual's desires or wants, "without drawing any distinction between better and worse pleasures." 14 It is a form of opportunism and serves to reinforce in students' minds that it is good to have one's pleasures fulfilled, rather than urging them to conceive of happiness by other criteria such as enlightenment. Pandering is opposed to trying to educate the desires and wants of students in light of a normative conception of what is best for human beings or how it is best for human beings to live, i.e., having a regard for the welfare of the individual. ${ }^{15}$ As Socrates puts it, if we assume that there is such a thing as health, and we understand health to mean a state of general well-being, then pandering creates a false sense of health or well-being as opposed to bringing that individual closer to a state of health or well-being. Today we might make the contrast in slightly different terms, but we can still appreciate Socrates' point.

Thus, cookery puts on the mask of medicine and pretends to know what foods are best for the body, and, if an audience of children or of men with no more sense than children had to decide whether a confectioner or a doctor is the better judge of wholesome and unwholesome foodstuffs, the doctor would unquestionably die of hunger. ${ }^{16}$

Teaching aspires to the good of the individual, which, as it implies, is to have a sense of what the good is as it relates to the particular individual. Socrates' analogy of the doctor is illuminative for two reasons. First, the doctor is someone who administers to the physical health of individuals, which requires knowledge of the human body, knowledge of what it is for the human being to be in a state of health as opposed to ill health, as well as knowledge of each particular individual who is to be treated. Similarly, we can conceive of teaching as administering to the intellectual and personal health of students, which requires knowledge of one or more disciplines, knowledge of what it is for human beings to come to know the respective discipline or disciplines, as well as knowledge of each particular individual who is to be taught. Second, an individual is physically healthy when each of her parts functions optimally and all of the parts are in harmonious alignment; it gives "order and proportion to the body." 17 In other words, health is determined by optimal and harmonious internal functioning of the whole. Similarly in teaching, intellectual health is measured by the incremental increase in knowledge, or the development of specific intellectual skills or faculties (memory, imagination, reasoning etc.), or the proper exercise of one's mind, and so on. In each case, the parts are simultaneously operating at their best and are working together to bring the whole into some kind of optimal functioning. To be healthy or to be educated is a matter of the organism or individual being in a perfect or optimal state, as determined in large part by the nature of the organism or individual itself. ${ }^{18}$ Hence, being healthy is not a matter of winning races or scaling mountains faster than others,

14 Plato, Gorgias, 501, p. 107.

15 Plato, Gorgias, 462, p. 43.

16 Plato, Gorgias, 464, p. 46.

17 Plato, Gorgias, 504, p. 111.

${ }^{18}$ Kant puts it nicely - if somewhat obliquely - when he says that, "since the agreement of the manifold in a thing with an inner character belonging to it as its end constitutes the perfection of the thing..." p. 173, Kant, Immanuel, The Critique of Judgement, translated with Analytical Indexes by James Creed Meredith (Oxford and New York: Oxford University Press). For Socrates, of course, intellectual health consists in "righteousness and 
and being educated is not a matter of winning quiz shows. An ability to do these things might be indicative of a person's being healthy or educated but they are not constitutive of it.

However, there is a relation of disanalogy between the doctor and the teacher, or alternatively, between administering to the health of an individual and educating an individual. ${ }^{19}$ A doctor is able to administer to the health of an individual without the involvement of the individual. Individuals can be unconscious whilst they are brought back to a state of health, and even when conscious their consciousness doesn't necessarily play a determining role in the healing process. An individual can either thwart or facilitate a healing process by the degree to which she cooperates with the doctor's requests: whether she takes the requisite number of pills at the requisite times, performs the requisite exercises, refrains from potentially detrimental activities, and so on. But the individual cannot will the healing process in the sense that physical processes of this kind are not within the jurisdiction of consciousness - at least according to the traditions of Western medicine. Education, however, is different from health in this sense because it requires the participation, and not just cooperation, of the student. The educative process involves the consciousness of the student. If education is more than pandering to a student's desires and wants, but also involves the transformation of those desires and wants in light of a normative ideal of what constitutes intellectual health, or a well-educated individual, then the individual must be aware of her original desires and wants; she must be cognizant of the recommended desires and wants, and cognizant of the supporting reasons in each case. Most importantly, she must be properly attuned to the means of evaluating these reasons. Individual consciousness, and the reflective activity of this consciousness, are integrally implicated in the educative process.

The second disanalogy is related to the first. It is possible to determine what it is for an organism to be in physical health, where physical health is conceived of on the model of an organism being in harmony with itself, based on our understanding of the organism. That this is possible in the case of intellectual or personal health is less clear because in the case of the individual, it is more difficult to differentiate the intellectual or personal "organism" from the one coming to understand the organism, they being one and the same. In other words, it is difficult to determine the essence of ourselves, over and above any perspective we might take with respect to ourselves, because those very perspectives are themselves partly, if not wholly, constitutive of the self we are trying to understand. It follows, therefore, that to see the self differently is, in a sense, for that self to be differently given - there are as many selves as there are views of the self. It doesn't follow from this, however, that intellectual or personal health is impossible, there being no "organism" as such for the self to be in harmony with. What does follow is that we cannot rest easy with our ideal for intellectual or personal health: the ideal must address both the individual and other individuals. It must be informed by a sense of its own fallibility; it must be brought into dialectical engagement with other ideals; it must be constantly tested and questioned; it must be continually taken up and revised in the living of our lives. We must also keep going back, as individuals and as a community, to the occasions and individuals in our own lives and in art that affect or profoundly speak to us, with the view to reminding and elucidating for ourselves their insights. Intellectual or personal health requires that the individual be in a kind of intraand intersubjective harmony, but also that self and self-understanding move towards greater deepening. Philosophical reflection brings us closer towards, and is itself constitutive of, intellectual or personal health.

Socrates sometimes argues as though the only legitimate alternative to oratory or any equivalent form of pandering in education is the discipline of philosophy itself. Certainly one of the most striking things about Socrates was his commitment to philosophy and the transformative power that it had over his life and the lives of those with whom he interacted. However, if we take into account his overall

moderation" (Gorgias, 504, p. 112). We can accept his argument, however, without necessarily having to accept this.

${ }^{19}$ I would like to thank Christopher Cordner for pointing the first of these out to me. 
understanding of philosophy and his view about the role of philosophy in human life, then it is possible to interpret him as saying that to be a proper student of a discipline - whether that discipline be history, music, literature, chemistry - is to have one's sense of what is valuable or important transformed, i.e., there is an intrinsic or necessary relationship between the transformative effects associated with being a student of that discipline and the discipline itself. As Socrates puts it: "A man who has learnt any subject possesses the character which knowledge of that subject confers." 20 A more accessible formulation of Socrates' point is to say that he wants to resist conceiving of the professions in terms of the acquisition of a certain competency or expertise, and to construe them rather as vocations in the true sense of the term, in which one is individually claimed and eminently improved by what one is called to do. It cannot be denied, however, that Socrates is adding the proviso that an implication of this transformative process, irrespective of the discipline that it is associated with, is that the individual has engaged in a reflective process characteristic of philosophy: "What did I think before?" "How has my thinking changed?" "What are my criteria for judging it as an improvement?" "What assumptions did I have that I no longer have?" And so on.

In order for this process to be possible we must resist a certain reductionism so pernicious in education for which the disanalogies between administering to the health of an individual and educating an individual are instructive. Even with a normative conception, no matter how minimal, of what intellectual health consists in or what it means to be an educated person, we must be careful not to reduce this to either a set of beliefs or a set of processes. Raimond Gaita is right to point out that in education we all too often start with the question of what students need to know or what students need to be able to do, and then focus on the optimal means by which to achieve this, drawing on the sociological and psychological theories of the day. ${ }^{21}$ In other words, there is a focus in education on what it produces - whether knowledge or competency - rather than on the process of coming to be educated. But for education to be genuinely transformative, it must engage the consciousness of the individual, alerting it to its own role in the transformative process. How, then, does one engage another's consciousness? It is impossible to do it either by threats or coercion, or by instruction - if "instruction" means instilling in them a set of propositional attitudes or beliefs. A teacher, in inviting students to engage reflectively with what they are learning, can at best only show what a discipline or subject can mean in the context of a life, i.e., she or he testifies to its transformative possibilities. As Gaita says, the teacher makes "something inspirational of her subject. . . In their teaching they will reveal the worth of the life they have given to teaching - the worth of their vocation." 22

There can be no manual or set of instructions for how to teach in this way. One's ability to inspire or engage students' consciousness, if it is to be genuine, derives from having been transformed by the discipline of study, which is itself a process of reflective engagement. It does not follow from this that teaching is done instinctively or unreflectively. Neither does it follow that teaching is not something we can be educated in, some of us being born with the knack and others not. To the contrary, teaching is not a knack but is something that we can be educated in, and the process by which we become educated in it is disciplined, demanding, and rigorous. It is disciplined, demanding, and rigorous, not because we are acquiring an extensive body of incredibly complex knowledge or because we are mastering an extensive set of difficult skills, but because we are coming to know our discipline and ourselves and our discipline in relation to others. We are coming to terms with the worth of what we do, both with respect to the discipline we study and our teaching of that discipline to others; we are moving to an ever deepening understanding of our discipline, ourselves as students of that discipline, and as teachers of it. Importantly, we are refining our beliefs and our practice in light of this

\footnotetext{
20 Plato, Gorgias, 460, p. 39.

${ }^{21}$ Gaita, Raimond, A Common Humanity, p. 230.

22 Gaita, Raimond, A Common Humanity, p. 231. He goes on to say that it cannot be the teacher's motive to inspire. "Teachers who set out to inspire have their attention in the wrong place and are too distracted from their subject to be able to offer anything deep no matter how many hearts they set afire."
} 
understanding; we are asking ourselves what is meant by such essentially contested concepts as "the child," "the learner," "knowledge," "wisdom," "expertise," etc.; we are asking ourselves what is worth learning and what is not worth learning; we are distinguishing between legitimate and illegitimate means of persuasion; and so on. ${ }^{23}$ It is, in other words, to engage philosophically with our respective discipline and to engage in the study of philosophy of education - the two being to an extent indivisible.

Kant makes a similar point in relation to genius. ${ }^{24}$ Although Kant restricts the concept of genius to certain outstanding fine artists - using it as a way to further demarcate the arts from the sciences and conceives of it as a birthright rather than anything that one could acquire over time, genius for Kant resonates with teaching as I have been discussing it. Fine art, Kant argues, is exclusively the product of genius: it cannot be produced according to a rule or concept by which we evaluate it because we cannot know this rule or concept in advance. ${ }^{25} \mathrm{It}$ is gathered from the performance. He makes two points about this. First, it doesn't follow from this that the performance is therefore unreflective or unintelligent. He writes in this regard that for fine art to be inspiration is not itself "a matter of inspiration, or of a free swing of the mental powers, but rather of a slow and even painful process of improvement, directed to making the form adequate to his thought without prejudice to the freedom in the play of those powers." 26 Second, it doesn't follow that deriving the rule from the performance is equivalent to being able to imitate the performance. Rather, it is to test one's ability at being able to follow the rule in one's own life, which may result in a radically different, but nonetheless authoritative, performance. ${ }^{27}$ To conceive of teaching on the model of genius does not preclude educating teachers, but it does necessitate that this education be of a philosophical kind.

\section{The Role of Philosophy}

It is no accident that Socrates' legacy is not in what he wrote, but in how he is represented in the dialogues of one of his own students. We also should not overlook the fact that although subsequent texts in philosophy of education have, as a rule, had an argumentative or narrative structure rather than a dialogical structure, they have also not had an instructional structure. While it is true that philosophy of education deals with questions concerning how to teach and what it is to teach well, the discipline hasn't felt compelled to produce manuals for teaching. This is a significant point because it reflects the understanding that the aim of philosophy/teaching is not to tell others how or what to do or think, but rather to inspire or lead by what the philosopher says and does, and, in the case of Socrates, what they have made of what they say in what they do. The persuasive force of Socrates, in his defense of the philosophical or examined life is not given by his arguments or any exceptional quality they might have had-it is not a function of his mere technical skill alone-but rather is a function of the significance that philosophy came to have in the context of his own life. ${ }^{28} \mathrm{He}$ demonstrates that an appropriate and effective way of responding to the aspiration to live well is to engage in honest philosophical reflection.

\footnotetext{
${ }^{23}$ Gaita, Raimond, A Common Humanity, "Truth and the responsibility of intellectuals" and "Goodness and Truth" and "Truth as a need of the soul", pp. 187-258.

${ }^{24}$ Kant, Immanuel, The Critique of Judgement, pp. 169-183.

${ }^{25}$ Kant, Immanuel, The Critique of Judgement, p. 169. He goes on to say that, "It cannot indicate scientifically how it brings about its product, but rather gives the rule as nature. Hence, where an author owes a product to his genius, he does not himself know how the ideas for it have entered into his head, nor has he it in his power to invent the life at pleasure, or methodically, and communicate the same to others in such precepts as would put them in a position to produce similar products."

${ }^{26}$ Kant, Immanuel, The Critique of Judgement, p. 174.

${ }^{27}$ Kant, Immanuel, The Critique of Judgement, p. 171.

${ }^{28}$ Gaita, Raimond, Good and evil, Chapter Fifteen, "Moral Understanding”, pp. 269-287.
} 
Honest reflection, because it must ensue from the individual if it is going to be transformational for that individual. Philosophical reflection for reasons which I now proceed to consider.

Socrates was of the view that our practices - how we live as individuals and as a society - are informed by our own assumptions about the nature of humanity and what constitutes power, happiness, and love, for example. He presumed the existence of an intimate and mutually conditioning relationship between conceptual understanding and the living out of a life. To live is to be implicated, either knowingly or unknowingly, in a set of values. I am suggesting that teaching is the same; that is, to teach is to be implicated, either knowingly or unknowingly, in a set of values. In his treatment of others, Socrates presumed that there is a gap (and in some cases a vast gulf) between what we think of as our conceptual understanding as evidenced in what we say, and our conceptual understanding as evidenced in what we do. Returning to the analogy of physical health and the idea that a healthy organism is an organism in harmony with itself, Socrates is making the claim that human beings are for the most part in ill-health Given this link between concepts and living, and the state of self deception in which individuals largely exist, Socrates demonstrated in his practice with others the power of philosophical reflection with respect to both of these. I am suggesting that given the similarities between living and teaching - both are connected with who we are, both are practices intimately linked with understanding, and both implicate us in a set of values - philosophy has a role to play in teaching as it does in life. It can make us aware of the gap between what we say we believe and what we show ourselves as believing in our practice; it can help us in the evaluation of those beliefs, enabling us to bridge that gap, thereby giving us greater self-awareness and our practice greater authenticity.

For Socrates, philosophical reflection consists simply in asking ourselves questions, defining what we mean by the words we use, generalizing from the particular, providing examples and counterexamples, identifying assumptions and implications of our commitments - all of the moves that we have come to identify as Socratic Method. Hence the question, "What is the good human life?" is translated by the Socratic Method into a question about "How should one ('T', 'we') live?" This is a potent translation because it shifts attention from determinations of "goodness" and "human life" to questions about how we live, as well as our reflections on how we live and what it is to live well. This questioning has three dimensions. First, we have to ask ourselves how we think we would like to live what for us as human being constitutes the ideal life? Second, who would we want to be? Third, what would we want to be like? In attempting to answer these questions we need to establish how truthful these answers are, and we do this by considering how they relate to what we already do and how we respond to what others do. To examine our activities in this way is to attempt to discover how we feel about the kinds of values, beliefs, and commitments that our activities give expression to: are we proud? ashamed? ambivalent? And so on.

Admittedly, professional philosophy dedicates itself, almost exclusively, to the provision of determinations of these concepts, so that any relationship philosophy might have had to the meaning of life has become somewhat attenuated; but to refer to Socrates' practice of philosophy is to show how it enables us to start from the particular (a child, a class, a lesson, an incident, an action) and by a process of careful excavation, identify an appropriate response in light of the reality of the situation, i.e., identifiable values, objectives, principles of justice, etc. Philosophy is a means of "going on" in an authentic manner; it enables us both to bring our commitments and our practices into greater accord, and also to evaluate them with a view to improving them. Hence, Socrates was able to show how philosophical reflection could bring people to an awareness of what they believed about the meaning of life, and to any discrepancy between what they said they believed and the beliefs their actions testified to, as well as provide them with the means to reflect upon the question of the meaning of life. Philosophical reflection is shown in the Gorgias to give Socrates' life greater authenticity and integrity, and to have the potential to do the same for others.

The accord between what Socrates believed and how he behaved and philosophy's central role within that is in stark contrast to the other interlocutors of the Gorgias: Gorgias, Polus, and Callicles. But it is by engaging these interlocutors in philosophical reflection that Socrates is able to bring them 
closer to an awareness of the gap between what they avow and how they live. He persists in calling for greater precision in Gorgias' definition of oratory: from oratory as "speech," to the "greatest and best of human concerns," and finally "as an ability to convince others by means of speech so you have others in your power." 29 The point of demanding accuracy and precision is not simply to do philosophy but rather to determine as accurately as possible exactly what Gorgias believes, for only then is Socrates able to reveal to Gorgias the implications of his belief, namely that he is offering his students great social and political power, without educating them in how to exercise that power judiciously. Socrates attempts to reveal the personal, social, and political ramifications of this implication. Similarly, Socrates uses his questioning of Polus to reveal Polus' underlying assumption that it is better - an individual is happier - if they have power over others and can do what they want, immune from punishment. In having Polus acknowledge and articulate this assumption (something he might not have done otherwise), Socrates is able to reveal to Polus how misconceived it is, and is able to demonstrate to Gorgias a very real consequence of his teaching, i.e., it has only served to reinforce Polus in his view. So again uncovering assumptions is important, not because it is to do philosophy as such, but because it is a means by which to discover, articulate, and evaluate what our commitments are and what follows for our practices; that it is such a means is what it takes for it to be philosophy - that is Socrates" point and the "point" of Socrates.

This brings us to Socrates' conversation with Callicles. Callicles is the most significant among the three interlocutors because he is the most sophisticated and persuasive, and is represented as being as opposed to philosophy as Socrates is in support of it. ${ }^{30}$ He purports to understand both Socrates' use of false shame in his conversations with Gorgias and Polus and his "verbal traps", and claims not to be a victim of them. ${ }^{31}$ Hence he is able to say what the others cannot say. Socrates pushes Callicles to define what he means by "better" with greater specificity, beginning with "more powerful," then "stronger," "gifted," "“more intelligent," "having more courage," 32 until finally Callicles concludes that "luxury and excess and licence, provided that they can obtain sufficient backing, are virtue and happiness". ${ }^{33}$ Socrates challenges Callicles' definition with images of what it is to be a victim of one's wants - he speaks of leaking pitchers and casks, and of the catamite - for he suspects that Callicles derives his definition of virtue and happiness from whom he envies: namely, powerful and influential people. And by demonstrating to Callicles that his definition extends to include the catamite, Socrates hopes to encourage Callicles to simultaneously self-correct his definition of "better," as well as his envy and what he thinks of as the object of his envy. Callicles resists such self-correction by ceding to the argument rather than answering as he really thinks in an argument - ironically - about the virtue of selfmastery, which, as it is understood by Socrates, is a form of self-correction as opposed to the repression of ineradicable desires and wants. ${ }^{34}$ Of the three interlocutors, Callicles is shown to be the most conflicted with himself. On the one hand he is making a claim about virtue and happiness that he refuses to reconsider, and on the other hand, he continues only "to oblige Gorgias"; he is the most involved in the conversation and in the way in which Socrates lives his life; he is the most incensed by what he perceives of as the "injustice" of Socrates" conversational technique, and so on. ${ }^{35}$

It is one of the points of the Dialogue that an individual who thinks as Callicles does about human virtue and happiness is ultimately going to be in contradiction with his or her self, and will be betrayed in his or her actions. Similarly, an individual who thinks as Socrates does about virtue and

\footnotetext{
${ }^{29}$ Plato, Gorgias, 449, 451, 452, pp. 23, 26 and 28 significantly.

30 Plato, Gorgias, 481, pp. 75-76.

31 Plato, Gorgias, 489, p. 86.

32 Plato, Gorgias, 488-492, pp. 85-90.

33 Plato, Gorgias, 492, p. 91.

34 Plato, Gorgias, 495, pp. 95-96.

35 Plato, Gorgias, 505, p. 114. Refer to 508, pp. 117-118 for a discussion of the relationships between sociability and morality.
} 
happiness is ultimately going to be in harmony with his or her self; i.e., for an individual to be in a state of health $i s$ for that individual to be moral or good. Socrates says at one point: "I don't claim to know that this is the truth, but I have never met anybody, present company included, who has produced a different opinion without making himself ridiculous." ${ }^{6}$ The analogy with teaching is that there are only certain ways for an individual to think about teaching, without his or her practice of it becoming inauthentic. As to what these ways of thinking about teaching are, as well as what the limits of them might be, I will leave for another occasion, except to comment that it will no doubt have to involve respect, in the Kantian sense, for one's discipline and one's students. For although I suspect there is a connection between philosophy and the kind of teaching that can be authentic, my aim is to establish philosophical reflection as a necessary condition for the possibility for greater authenticity in teaching. The question of its sufficiency is a separate one.

To return to the Gorgias, the point is that each of the interlocutors, in the simultaneous process of uncovering and determining their commitments, is responding in part to Socrates' arguments, but also in part to their felt responses and what they believe would be the response of others to their beliefs. There are repeated references to this by the interlocutors and by Socrates himself. ${ }^{37}$ Polus, for example, comments: "Who do you suppose is going to admit that he doesn't know and can't teach the nature of right? It is exceedingly ill-bred to have caused the conversation to take such a turn." 38 Each of the interlocutors is claimed by Socrates' legitimate use of dialectic and rhetoric, the point being that to use one or the other without a commitment to truth is opportunistic in the case of rhetoric and idle in the case of philosophy. ${ }^{39}$ The issue is not so much whether Socrates is right or wrong in what he says.

I am not speaking dogmatically from the certainty of assured knowledge; I am simply your fellow-explorer in the search for truth, and if somebody who contradicts me is obviously right I shall be the first to give way. ${ }^{40}$

The issue is rather that, in being either right or wrong, there is at least an accord between the choices that he makes, how he lives his life, how he engages with others and what are his commitments, as well as the reasons he gives for having those commitments. He has an authenticity or integrity that we cannot help but find compelling and that philosophical reflection is in some way crucial for this development. He serves as a model for what we might become. ${ }^{41}$

I have focused on the Gorgias, but of course philosophy of education extends from Socrates and Plato until the present day. It is important for students to be introduced to this tradition, because formal education is not a unitary or an internally coherent and consistent whole. It is riddled with the inconsistencies, contradictions, and conflicting directives that mediate our relations with young people. Education has this nature partly because of its long and varied history and partly because of the

\footnotetext{
36 Plato, Gorgias, 509, p. 119.

${ }^{37}$ I am drawing on the following literature: Illham Dilman, Morality and the Inner Life: A Study in Plato's "Gorgias" (London: Macmillan Press, 1979); Charles Griswold, Jr "Plato’s Metaphilosophy: Why Plato wrote dialogues" in Platonic Writings, Platonic Readings, edited by Charles L. Griswold, Jr. (London and New York: Routledge, 1988) pp. 143-170; Charles H. Kahn, "Drama and Dialectic In Plato's Gorgias" in Oxford Studies in Ancient Philosophy, Volume One, Edited by J. Annas (Oxford: Clarendon Press, 1983), pp. 75-121; Richard McKim, "Shame and Truth in Plato's 'Gorgias"' in Platonic Writings, Platonic Readings, pp. 34-48; Alexander Nehemas, "What did Socrates teach and to whom did he teach it?" in Review of Metaphysics, 46, Dec 92, pp. 279-306.

${ }^{38}$ Plato, Gorgias, 461, p. 41. Other references include, 481, p. $74-75$ when Callicles implies that Socrates can't be serious because if what he said were true, "we shall have human life turned completely upside down."

${ }^{39}$ For a contemporary defense of the cognitive respectability of the emotions and rhetoric continuous with Plato's, refer to Catherine Z. Elgin's book Considered Judgment (Princeton: Princeton University Press, 1999), Chapter Five, "The heart has its reasons" and Chapter Six, "Shifting Focus", pp. 146-204.

40 Plato, Gorgias, 506, p. 115.

41 Plato, Gorgias, 510, p. 121.
} 
different ideas that have, over the centuries, informed and shaped it. So, for example, we have taken primarily from Rousseau his idea that childhood is for childhood's sake, with childhood being understood as a time of playfulness, purity and innocence - equivalent to a state of grace. On the other hand, we take from Locke an entirely different conception of childhood, which informs other contemporary educational practices. Childhood, in Locke's view, is not radically separated from adulthood. Acknowledging that children have less reason the younger they are, he is nonetheless of the view that they do possess reason and can therefore be reasoned with. Similarly, it is natural to assume, given our experience of children from the perspective of adulthood, that childhood is a state of dependency and therefore deficit. But Dewey serves as a corrective here, identifying at least two strengths of childhood - dependence and plasticity - and seeing childhood as already rich in activity and hence growth. ${ }^{42} \mathrm{He}$ writes in this regard that "children are themselves marvelously endowed with power to enlist cooperative attention of others. . . few grown-up persons retain all of the flexible and sensitive ability of children to vibrate sympathetically with the attitudes and doings of those about them." 43

Going back once more to Plato, we have inherited a conception of the learner as someone who, with the advantage of years of self-discipline, is able to excise himself from life's distractions and contemplate abstractions; a solitary, still, quiet, and, to a certain extent, remote individual who feels more comfortable in the realm of ideas rather than the realm of people with their shifting demands and practicalities. This conception of the learner can be contrasted with a conception of the learner that has its origins in Rousseau and culminates in the work of Dewey. The paradigmatic learner is not the contemplative sage but the active young child industriously mastering all of life's activities. These in a sense constitute the limits within which other positions locate themselves.

I have been describing classical philosophy of education in broad-brush strokes and recognize that more careful study reveals tensions within all of these positions. But my remarks should serve to illustrate that the history as well as the practice of philosophy of education can enable teachers to disentangle the contradictions inherent in education. Further, it can give them a sense of how problems within the classroom and within the institution can be clarified by way of a theoretical or philosophical perspective. It has been argued by Greene and by some of those within critical pedagogy that teachers need to be exposed to classical and contemporary theories - Greene speaks of disciplines - so that they may be in a position to use these theories to critically reflect on social and educational practices, and to be critical of the theories themselves insofar as they have legitimized certain social and educational practices over others. ${ }^{44}$

To teach is to be intelligently, responsively, and critically immersed in the abundance of day to day life - its practicalities and particularities - and so is a practice for which philosophical reflection is necessarily foundational.

\section{About the Author}

Megan Laverty is Associate Professor of Philosophy and Education in the Department of Arts and Humanities at Teachers College, Columbia University. She has taught at Montclair State University and The University of Melbourne. Her research interests are philosophy for/with children, philosophy of education and moral philosophy. Please address correspondence to Laverty@tc.edu.

\footnotetext{
${ }^{42}$ Dewey, John, Democracy and Education (New York: Macmillan Company, 1944), p. 42.

${ }^{43}$ Dewey, John, Democracy and Education, pp 43.

${ }^{44}$ See Weiner, Eric, "Making the Pedagogical (Re)Turn: Henry Giroux’s Insurgent Cultural Pedagogy" in $J A C$, Volume 21, Number 2, Spring 2001.
} 